\title{
What Explains German Export Performances? Spatial Econometric Evidences: 1995 to 2014
}

\author{
Wen Yang ${ }^{1}$, Yi-Cheng Liu $^{2}$, Chao-Cheng Mai ${ }^{3,4}$ \\ ${ }^{1}$ Department of Statistics, Tamkang University, New Taipei City, Taiwan \\ ${ }^{2}$ Department of International Business, Tamkang University, New Taipei City, Taiwan \\ ${ }^{3}$ Department of Industrial Economics, Tamkang University, New Taipei City, Taiwan \\ ${ }^{4}$ Research Center for Humanities and Social Sciences, Academia Sinica, Taipei, Taiwan \\ Correspondence: Chao-Cheng Mai, Research Center for Humanities and Social Sciences, Academia Sinica, 128 \\ Sec. 2, Academia Rd., Nankang, Taipei, Taiwan.
}

Received: May 25, 2017

doi:10.5539/ibr.v10n9p17
Accepted: June 22, 2017

Online Published: August 1, 2017

URL: https://doi.org/10.5539/ibr.v10n9p17

\begin{abstract}
German exports achieved outstanding performances, yet there is lack of research utilizing spatial econometric evidences. This paper explores four explanations and evaluates their empirical contributions: (i) German exports were highly correlated to its imports. Thus, its exports built upon bilateral trade flows. (ii) German exported to countries with high GDP per capita with the capability and the demand of high-quality and less price-elastic goods. (iii) It exported to countries with economic integration with other countries such as free trade agreements. (iv) Its exports broadened from Europe to other countries in America and the Asia Pacific region with increasing total export-volume growth. Thus, German exports benefited from the free trade flow to a few EU member countries, those are close geographically and culturally to Germany. The empirical evidence also points out that the changing geospatial distribution of German exports is another key factors to its export success. The spatial Durbin model was identified to be the best fit model of all after a series of tests. Decisive determinants of its exports performance were found through the estimation besides geospatial analyses of its exports by employing Moran's $I$.
\end{abstract}

Keywords: spatial econometrics, spatial effects, German exports distribution, exports determinants

\section{Introduction}

German exports have long been well documented, and their performances and competitiveness widely studied. However, there is a significant lack of research on how Germany achieved outstanding export performances using spatial econometric evidences. This paper aims to fill the gap in the existing literature by investigating the changing geospatial distribution of its exports and identifying determinants to its outstanding performances over decades by applying spatial econometric models.

We first employ Moran's $I$ which is a useful indicator of the spatial association. The statistic of Moran's $I$ can illustrate and show the decomposition of the association into spatial clusters (it is the "country" in the case of this study) and, therefore, it is more effectively observe and assess changing geospatial distribution of German exports during the period of this study.

Then we examined the explanatory power of the spatial lag model (SLM) or the spatial error model (SEM), it is much better off than the conventional Pooled Ordinary Least Squares (OLS) by comparing the R-squared of each. The log-likelihood test, the LR test, and the robust LR test were employed to determine if the SLM is more favored than the SEM for the panel data of this study. The Hausman test was also utilized to decide that the fixed effects model is more appropriate than the random effects model. Wald test was used to determine that the spatial Durbin model (SDM) is more favored than the SLM.

The SDM was finally identified to be the best fit model of all after the series of aforementioned tests. Decisive factors of German exports performances were found through this study besides geospatial analyses of the exports by employing the Moran's $I$.

The spatial Durbin model was estimated covering the period 1995-2014. Empirical evidences show that German 
exports were highly correlated to its imports. This signifies that German exports built upon those already close economic relations. Trade flows are not only one-way exports. Imports are highly correlated to German exports. This applies as well to countries such as mainland China, Switzerland, Austria, and Italy. In addition, German goods are mainly exported to countries with high GDP per capita. Thus, these countries were capable of purchasing high-end luxury automobiles and demanded price-inelastic and high-quality German goods. German exports also benefited from the free trade flow between a few EU member countries, who are close geographically, linguistically, and culturally to Germany. Overall, Germany broadened its exports from Europe to countries in America and the Asia-Pacific region with increasing export volumes during the period of this study.

The remainder of this paper is structured as follows. Section 2 discusses outstanding performances of German exports over a few decades. Section 3 explains how variables were adopted and estimation approaches implemented. Section 4 analyzes empirical findings. The conclusion is drawn in the last section.

\section{Outstanding Performances of German Exports}

German exports persistently run a huge current account surplus. It comes in the second in world exports after the USA and is the top one when services are disregarded and only commodities are considered (Sinn 2006). In fact, its exports were the top in the world by the total volume for decades until 2008. It continued to rank in the top three after the USA and mainland China from 2010 onwards. Excessively high wages are defended by unions and the welfare state against the forces of international low-wage competition. These efforts destroy the labor-intensive sectors and drive too much capital and labor into the capital-intensive export sectors, causing highly value added in exports (Sinn 2006). For instance, studies conducted by Rothwell (1981) and Anderton (1999) found that UK products were of a lower product quality in comparison with their German counterparts by employing conventional Probit and Truncated Regression Models.

In the 1990s, in particular, the external environment underwent significant changes. The world experience increased globalization. The changes (the elimination of the "Iron Curtain" in Eastern Europe, EU enlargement and the establishment of EMU) raise the question as to whether the importance of key determinants of German exports, namely, export market trends and the price competitiveness of the German industries, might have shifted across different periods and in different regions. For instance, Stahn (2007) provided empirical evidences that the long-run relative price sensitivity of German exports has been on a downward trend since the 1990s. Export supply or export demand shifts in favor of less price-elastic products.

It is also worthwhile to note that Germany's export market share increased since 2000, while most industrial countries experienced declines. According to empirical findings covering the period 1993-2005 of Danninger and Joutz (2007), they identified four reasons for the success of German exports: cost competitiveness improved, closely tied to fast growing trading partners, increased demand for capital goods, and regionalized production of goods (e.g. offshoring). The dominant factor explaining the increase in market share is trade relationships with quickly growing countries. Regionalized production in the export sector also played a role. In addition, the study of Jannsen and Kooth (2012) found that while the global financial crisis had a strong impact on economic activity in Germany, the impact of the Euro area crisis on economic activity in Germany has so far been relatively mild. Trade flows by region reveal that German firms have recently redirected their exports towards the remaining growth spots of the world economy, particularly to Asia's emerging economies.

Two of the elements were singled out for its long-term current account surpluses by Simonazzi et al. (2013): (1) the effects of eastward enlargement, (2) the impoverishment of the productive matrix of peripheral countries and the quality composition of trade flows.

However, there is a lack on prior literature that has taken the spatial effects into account. The ability of German export earnings is seen as a key indicator of competitiveness and the ability to generate its wealth. The export success is a potential explanation for Germany's contrasting world trade performances (Roper and Love 2002). It is intriguing to perform a further research to examine whether German exports behavior has changed. This motivates us to conduct this study on what factors make German exports to be so competitive and how it achieved the outstanding export performances over decades from a spatial econometric perspective.

\section{Data and Estimation Approaches}

\subsection{Data and Variable Definitions}

Previous papers identifying factors influencing exports growth and geographic distribution of advanced economies were reviewed. These earlier studies provided appropriate factors in interpreting Germany's changing exports destinations over the years. 
The nexus of exports, imports, and economic growth has been frequently studied in the past decades. It had been found in empirical results of prior literature (Fung et al. 1994, Esfahani 1991, Anderson and Marcouiller (2002), Yasar, M. and Paul, C. 2007, Schott, P. 2010, Eichengreen et al 2004) that there exists cointegration among exports, imports and industrial outputs in many countries, including both advanced and industrializing economies. Thus, it is assumed that exports and imports are correlated and there is a positive relationship between exports and imports.

Effect of the foreign exchange rate uncertainty on prices and international trade volume has constantly been researched in many previous studies: Hooper and Kohlhagen (1978), Bartram (2004), and Belke et al. (2013). The present paper uses foreign exchange rates of the Euro to the USD $(E R)$ to examine impacts of exchange rate movements on German exports. It is noteworthy that the Euro appreciated more than $40 \%$ against the USD in the beginning of this century and started depreciating sharply during the European sovereign crisis happened in 2010 .

The relationship between exports and GDP per capita of the trading partner was examined in early literature (Balassa, B. (1978), Aten, B. (1997), Anderson and Marcouiller (2002), Schott, C. (2010). and Hwang et al (2010)). In addition, the empirical findings of Eichengreen et al. (2004) showed that GDP per capita of the importing country has a positive relationship with exports of the exporting country.

Anderson and Marcouiller (2002) addressed that the soundness of the political and legal system of a country is vital to the development of the international trade. Political and country risks are cautiously and constantly assessed by the exporters, though there is often exports insurance provided by many governments to support and facilitate the country's exporting industries. Prior literature on exports growth also frequently took the risks into consideration (Katsikeas et al. 1996, Morrow et al 1998 and Eichengreen et al. 2004). In addition, KOF Globalization Index measures various dimensions of an indi vidual country, in particular, political risk. The index is produced by the Swiss Federal Institute of Technology in Switzerland. This index is widely employed as a proxy variable of the risk in this field (Agostino et al 2010). It is regarded that the risk of the importing country is negatively related to exports.

The relationship between exports and outward foreign direct investment (OFDI) is shown to be highly correlated in prior empirical studies (Egger (2001), Egger and Pfaffermayr (2004), Yeaple (2003), Pain and Wakelin (1998), Greenway and Kneller (2007), and Ekoholm et al (2007)). Thus, OFDI has already been recognized as an exports substitute with respect to changes in transport costs, complements and other determinants.

Trade and Foreign Direct Investment (FDI) are generally recognized as the two main channels of economic integration. The regional economic integration relates to trade creation, trade diversion, and the 'redirection' of FDI from non-members to member countries of the regional economic integration. Effects of economic integration on exports has been scrutinized in previous research (Katsikeas et al. (1996), Bjorvatn (2004), Winters (1985)). The term: "economic integration" has become more frequently utilized nowadays. Balassa (1961) defined that economic integration covers various forms such as free trade areas, customs unions, common markets. It is often suggested that exports to the country joining the economic integration will rise while those elsewhere fall. Thus, it is reasonable to expect a positive relationship between economic integration and exports.

The following six explanatory variables are therefore chosen: total amounts of German imports from its 30 largest exports partner countries (IMPORT), The foreign exchange rates of the Euro to the USD (ER), GDP per capita of German 30 largest exports partner countries $(G D P P C)$, outward foreign direct investment from Germany to 30 largest exports partner countries $(O F D I)$, political and country risks of German 30 largest exports partner countries $(K O F)$, the level of the economic integration of the 30 largest exports partner countries $(E I)$, and dependent variable: total amounts of German exports to its 30 largest exports partner countries (EXPORT). We construct a panel dataset for the estimation of the spatial econometric models by utilizing the above variables. Data for IMPORT, GDPPC, and EXPORT are downloaded from the Datastream (the electronic data bank). The OFDI data is provided by the Organization for Economic Cooperation and De velopment (OECD) website. The $E I$ data is judged by the level 1-4 according to the level of each country's free trade agreements signed with reference from the World Trade Organization (WTO) website. The KOF uses the KOF Index produced by the Swiss Federal Institute of Technology. The descriptive statistics of these variables are exhibited in Table 1. 
Table 1. Descriptive Statistics of the Variables

\begin{tabular}{|c|c|c|c|c|c|c|c|c|c|c|c|c|c|c|}
\hline \multirow{2}{*}{$\begin{array}{c}\text { Year } \\
\mathrm{s}\end{array}$} & \multicolumn{2}{|c|}{ EXPORT } & \multicolumn{2}{|c|}{$I M P O R T$} & \multicolumn{2}{|c|}{$G D P P C$} & \multicolumn{2}{|c|}{$E R$} & \multicolumn{2}{|c|}{$K O F$} & \multicolumn{2}{|c|}{$O F D I$} & \multicolumn{2}{|c|}{$E I$} \\
\hline & Mean & Std & Mean & Std & Mean & Std & Mean & Std & Mea & Std & Mean & Std & Mea & Std \\
\hline All & 224078 & 310141. & 171890. & 250176 & 20796. & 19026. & 526.1 & 2259.3 & 70.1 & 14.3 & 1746.9 & 6259.2 & 2.87 & 1.0 \\
\hline 199 & 189988.8 & 77433.5 & 156939.5 & & 17458.0 & 16440.1 & 137.57 & 508.08 & 62.6 & 16.5 & 1010.1 & 2040.3 & 2.50 & 0.9 \\
\hline 199 & 181147.6 & 248525.9 & 149433.0 & 219401.4 & 17761.0 & 16557.8 & 141.07 & 522.01 & 63.8 & 16.3 & 1487.2 & 3579.6 & 2.50 & 0.9 \\
\hline 199 & 140119.2 & 191129.7 & 112978.2 & 163213.4 & 18295.4 & 17076.0 & 143.96 & 533.13 & 65.3 & 16.0 & & 2132.4 & 2.50 & 0.9 \\
\hline 199 & 134606.7 & 188314.7 & 106999.0 & 153889.5 & 18572.1 & 17501.8 & 334.35 & 1500.9 & 66.5 & 16.0 & 2428.3 & 8162.3 & 2.50 & 0.9 \\
\hline 199 & 137039.6 & 193967.9 & 104950.9 & 148545.6 & 19070.2 & 18150.0 & 356.76 & 1616.9 & 67.7 & 15.3 & 3062.4 & 9061.8 & 2.50 & 0.9 \\
\hline 200 & 130813.1 & 187351.4 & 106991.3 & 150939.9 & 19890.3 & 19045.7 & 319.64 & 1416.1 & 68.9 & 15.2 & 1228.3 & 6450.7 & 2.60 & 0.9 \\
\hline 200 & 129624.8 & 183148.3 & 99555.70 & 138272.3 & 19966.2 & 19128.5 & 420.83 & 1958.4 & 69.5 & 14.6 & 1062.0 & 9860.9 & 2.60 & 0.9 \\
\hline 200 & 129902.1 & 181384.9 & 93957.17 & 128341.7 & 20145.1 & 19305.2 & 385.44 & 1765.5 & 69.7 & 14.1 & 555.78 & 3509.6 & 2.67 & 0.9 \\
\hline 200 & 162875.1 & 222148.0 & 117849.9 & 159660.2 & 20474.2 & 19389.6 & 574.41 & 2156.8 & 70.2 & 14.0 & 156.01 & 2964.6 & 2.60 & 0.9 \\
\hline 200 & 198372.5 & 267925.6 & 143129.3 & 193023.1 & 21122.5 & 19838.6 & 578.30 & 2171.8 & 71.1 & 13.8 & 70.03 & 5894.2 & 2.80 & 1.0 \\
\hline 200 & 240024 & 298264.9 & 165086.9 & 222648.0 & 21523.7 & 20048.0 & 619.49 & 2333.6 & 71.5 & 13.1 & 1870.3 & 4742.3 & 2.87 & 1.0 \\
\hline 200 & 239008.5 & 310255.7 & 180713.2 & 243528.6 & 22097.9 & 20439.2 & 610.11 & 2296.8 & 72.2 & 13.0 & 3006.1 & 5853.7 & 2.93 & 1.0 \\
\hline 200 & 283386.3 & 364017.5 & 210644.2 & 279130.0 & 22654.3 & 20940.4 & 617.72 & 2326.9 & 73.1 & 14.0 & 4179.3 & 10098. & 3.23 & 0.9 \\
\hline 200 & 335137.9 & 421032.9 & 254282.1 & 338823.1 & 22629.2 & 20694.0 & 613.62 & 2313.0 & 73.11 & 13.4 & 601.75 & 5944.0 & 3.23 & 0.9 \\
\hline 200 & 242108.1 & 302641.9 & 183853.3 & 246967.0 & 21598.7 & 19593.8 & 720.33 & 2720.8 & 73.11 & 13.0 & & 6034.8 & 3.20 & 0.9 \\
\hline 201 & 285997.6 & 348957.6 & 222209.7 & 300099.2 & 22125.7 & 20035.2 & 637.06 & 2402.8 & 73.1 & 12.8 & 3242.7 & 5820.8 & 3.23 & 0.9 \\
\hline 201 & 338603.9 & 416321.3 & 266861.3 & 353653.5 & 22501.1 & 20161.1 & 642.26 & 2431.9 & 72.6 & 12.9 & 2199.2 & 6281.3 & 3.20 & 0.9 \\
\hline 201 & 319757.8 & 392174.3 & 244354.3 & 326591.6 & 22514.5 & 19906.5 & 721.09 & 2751.0 & 72.8 & 12.8 & 2925.8 & 7980.5 & 3.20 & 0.9 \\
\hline 201 & 320061.5 & 394132.2 & 246023.9 & 327212.2 & 22666.0 & 19923.4 & 738.39 & 2805.8 & 72.8 & 13.1 & 1382.2 & 3425.7 & 3.27 & 0.9 \\
\hline 201 & 358923.9 & 446741.0 & 270992.4 & 360950.2 & 22865.8 & 19980.5 & 1211.4 & 4912.2 & 72.8 & 12.9 & 1746.9 & 6259.2 & 3.33 & 0.8 \\
\hline
\end{tabular}

\subsection{Spatial Model Specifications}

The social and natural sciences typically focused on how to describe the connection between single consequences and a group of explanatory variables. Studies on the spatial econometrics have been increasing ever since Anselin (1988) tested the spatial dependence properties in regression models. That is to say, it builds geographic variables, the data with the geographic characteristics, into research models. It greatly enhances the effectiveness and capability of research models.

Spatial dependence is defined as the existence of spatial correlation characteristics among neighboring areas. In other words, similarities of some certain factors may bring about the spatial clustering of neighboring areas. Spatial correlation is used to interpret similarities of neighboring areas. Spillover effects could appear among the neighboring areas if the similarity of neighboring areas is very high.

Spatial autocorrelation analysis is a useful method of judging if there is spatial dependency among neighboring areas, and whether clustering and spillover effects exist among neighboring areas. There are several tests often utilized to identify if spatial correlation exists among neighboring areas, such as: Moran's $I$ (Moran 1950), Geary's C (Geary 1954), Getis-Ord G (Getis and Ord 1992). Moran's $I$ is one of the most frequently adopted by researchers. The statistic of Moran's $I$ always lies between -1 and 1. The sign of the Moran's $I$ values suggests the types of spatial autocorrelation.

Local Indicators of Spatial Association (LISA), a useful indicator of the spatial association, was developed by Anselin (1995). Hence, spatial autocorrelation can be observed from the Moran's Scatter Plot. The scatterplots illustrate and show the decomposition of the association into spatial clusters of similar high or low values and clusters of dissimilar values. The scatterplots assess the existence of outliers. It is the "country" in the case of this study. 
Positive spatial associations indicate spatial clustering of similar values (High-High, values above the mean or Low-Low, values below the mean). It is structured such that in High-High (the first quadrant), are countries with high export volumes, and the ones whose neighbors also have high export volumes. In the case of Low-Low (the third quadrant), countries have low export volumes, whose neighboring countries also have low levels of export volumes.

Meanwhile, Low-High (the second quadrant) or High-Low (the fourth quadrant) represents the negative associations and spatial clustering of dissimilar values. Thus, countries with low export volumes are at the location near neighbors with high export volumes. In the case of High-Low, it represents those countries with high export volumes but are located near neighbors with low exports volumes.

Our analysis carried out the estimation from 1995 to 2014. To be manageable, we only present tables with the results obtained from Moran's $I$ statistic in selected years. For example, it covers the beginning year of this study, 1995, and the first year when the high-technology bubble burst, 2001. Also, 2007 and 2009 are the years before and after the US subprime crisis. Furthermore, negative impacts of the European sovereign crisis can be observed from year 2011 to 2014 . These results can be used to analyze the changing geospatial distribution of German exports during the period of this study.

It is necessary to employ spatial econometric models if the panel data is identified with spatial dependence properties, because the investigation results can be affected if the data are subject to changes of the spatial location.

Three models (spatial lag model (SLM), spatial error model (SEM), and spatial Durbin model (SDM)) are commonly employed to estimate the spatial panel data though there are some other spatial econometric models. All spatial econometric models are based upon the traditional regression model, ordinary least square (OLS) according to Figure 1. The SDM includes an additional explanatory variable: $W X \theta$ in comparison with the SLM (see Figure 1 below). It represents exogenous interactive effects of neighboring areas. There is no exogenous interactive effects of neighboring areas if $\theta=0$ and therefore, the SLM is a better-fit model than the SDM in interpreting the spatial dependency of the panel data. Meanwhile, the SEM is a better fit model than the SDM in interpreting the spatial dependence if $\theta+\delta \beta=0$.

The OLS model can be structured below (see Equation 1). It is supposed that the panel data have both spatial $\left(\boldsymbol{\mu}_{i}\right)$ and time $\left(v_{t}\right)$ fixed effects.

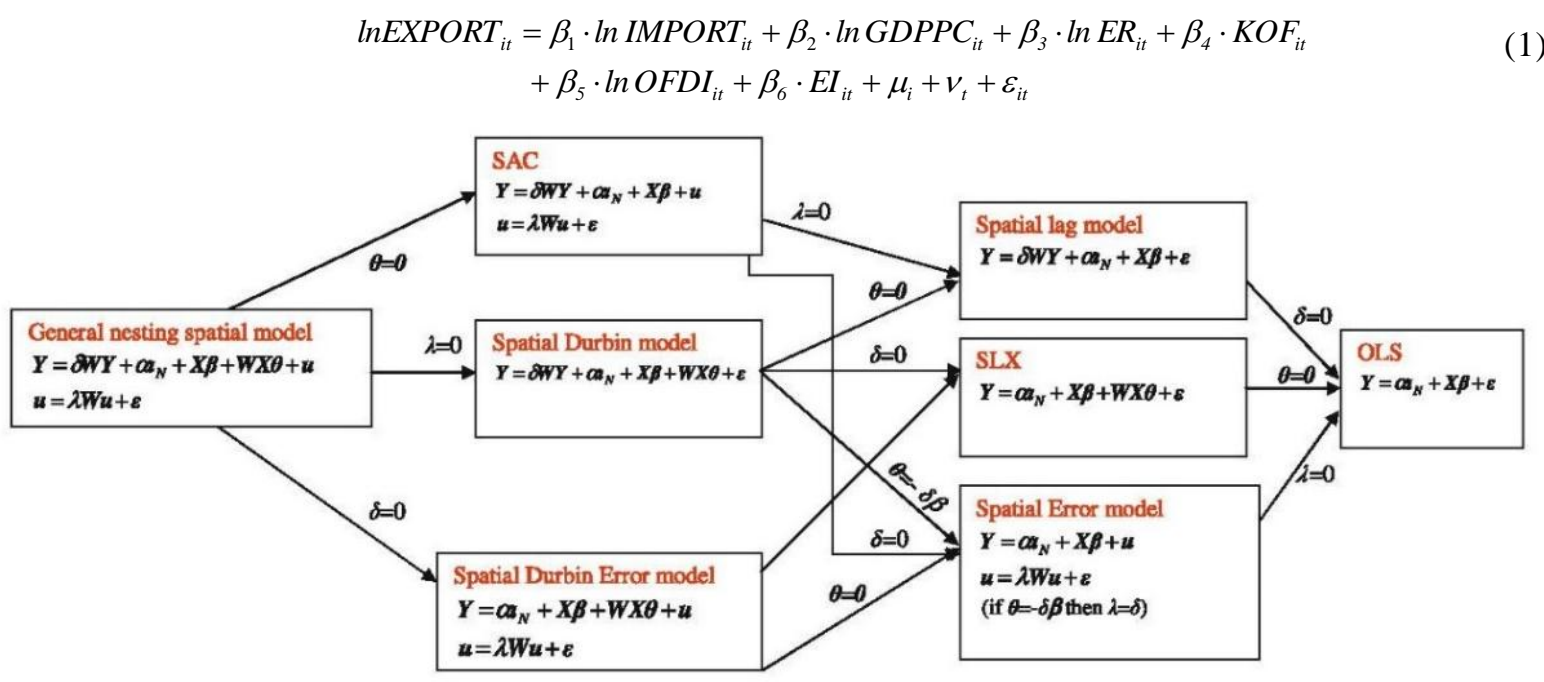

Figure 1. The relationships between different spatial dependence models for cross-section data (source: Halleck Vega and Elhorst 2012)

\section{Empirical Results}

Results of Moran's $I$ exhibit an intriguing and unique geospatial changes of German exports (see Table 2 and Figure 2). USA and the mainland China have consistently been categorized in the High-High quadrant during the period of this study. These two countries and their neighboring countries have been the major export destinations for years. The emergence of Mexico at the High-High quadrant in 2007 and from 2011 to 2014 implies increasing market shares of German exports in the Northern American countries. This may also be attributed to the NAFTA (North American Free Trade Agreement). On the other hand, Singapore started to be categorized at the High-High quadrant from 2011, 2012, and 2014. In addition, Australia was categorized at the High-Low 
quadrant in 2007 and from 2011 to 2014. These signify that German began to emphasize the importance of Asia-Pacific markets and attempted to catch up with the rapid and high economic development in this region. Therefore, it broadened its exports to many other East Asian countries in the recent years.

Interestingly, German exports to member countries of the European Union did not appear to be significant large (see also Figure 2). There were no EU countries categorized in the first quadrant though it ideally should benefit from the free trade flow under the European Union system in terms of economic integration and geographical proximity. Switzerland, Italy, and Austria were categorized at the High-Low quadrant and were consistently its main exports countries in Europe at this period, while Romania was categorized at the High-Low quadrant and emerged to become significant German exports destination from 2011 onwards. In the case of the Switzerland, Italy, and Austria, cultural proximity (German-language area) and their long-term allegiant relationship might be the main explanation of their significance to German exports. A consequence of these three countries all sharing borders with Germany, are therefore geographically much closer than other EU member countries. In the case of Romania being a stand-alone country of the main German exports country in the EU. Especially, in Central and Eastern Europe, this may be attributed to Romania playing a significant role in assembling and/or pure vertical and/or export planform for German exporting industries. Blonigen et al. (2007) suggested that these re-exports resulted from its lower production costs such as labor, land, and other factors.

Overall, results of the Moran's $I$ clearly show us that Germany exports have maintained_the USA, China, Switzerland, Italy, and Australia as its major export destinations over the past two decades. It also, further expanded and strengthened its market shares in other North American countries. It also broadened its export destinations largely to many Asia-Pacific countries. In short, it has expanded and diversified its export destination countries with increasing export-volume growth over the past two decades.

Table 2. Relative Presence of Countries and Municipalities in Four Quadrants EXPORT according to Moran's I

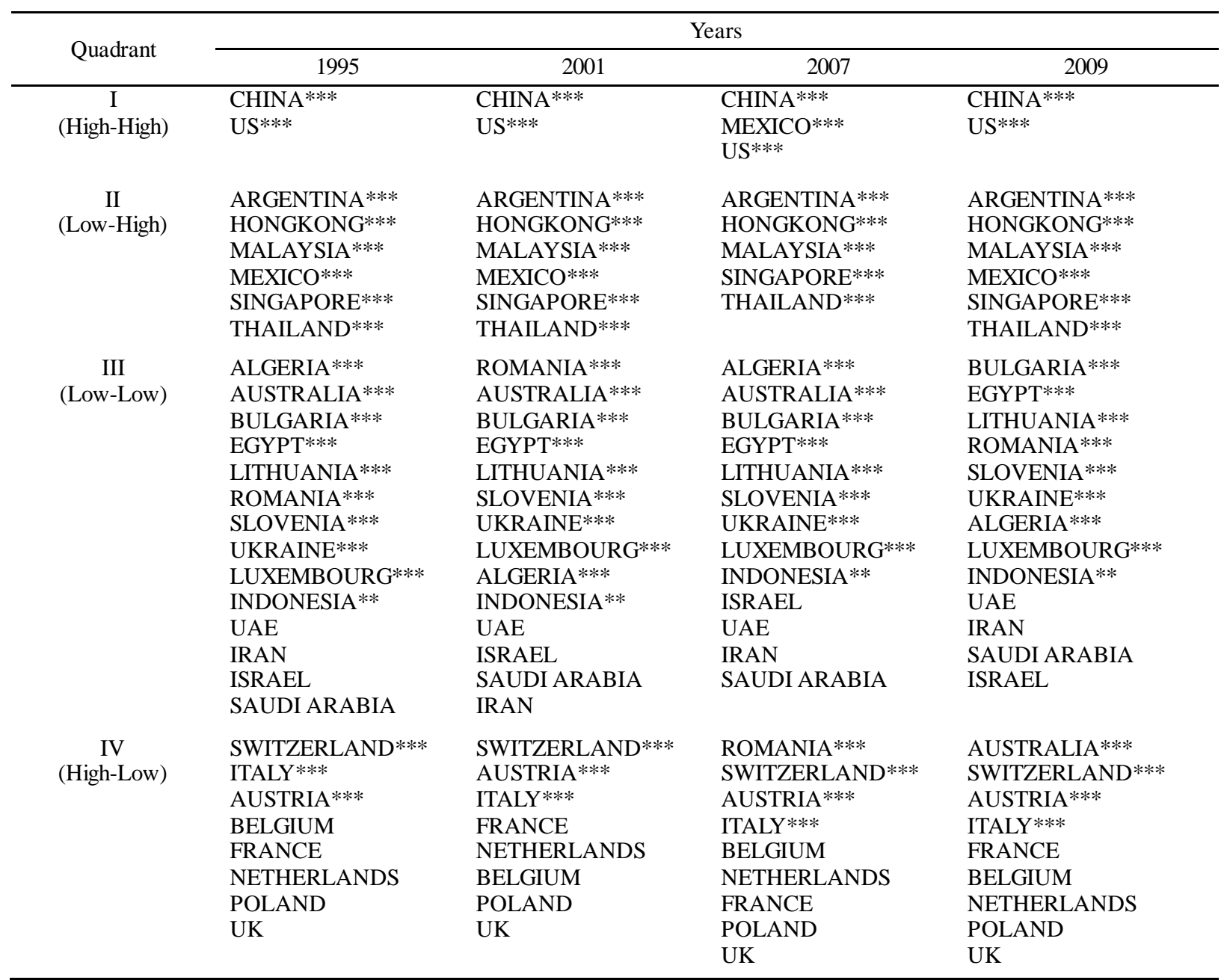

Notes. * significant at the level $0.1 * *$ significant at the level $0.05 * * *$ significant at the level 0.01 
Table 3. Relative Presence of Countries and Municipalities in Four Quadrants EXPORT according to Moran's I (cont.)

\begin{tabular}{|c|c|c|c|c|}
\hline \multirow{2}{*}{ Quadrant } & \multicolumn{4}{|c|}{ Years } \\
\hline & 2011 & 2012 & 2013 & 2014 \\
\hline \multirow{4}{*}{$\begin{array}{c}\text { I } \\
\text { (High-High) }\end{array}$} & CHINA*** & CHINA**** & CHINA*** & $\mathrm{CHINA}^{* * *}$ \\
\hline & MEXICO $* * *$ & MEXICO $* * *$ & MEXICO $* * *$ & MEXICO $* * *$ \\
\hline & SINGAPORE $* * *$ & SINGAPORE $* * * *$ & US*** & SINGAPORE $* * * *$ \\
\hline & US*** & US*** & & US*** \\
\hline \multirow{5}{*}{$\begin{array}{c}\text { II } \\
\text { (Low-High) }\end{array}$} & ARGENTINA $* * *$ & ARGENTINA $* * *$ & ARGENTINA $* * *$ & ARGENTINA $* * *$ \\
\hline & HONGKONG*** & HONGKONG*** & HONGKONG*** & HONGKONG*** \\
\hline & MALAYSIA $* * *$ & MALAYSIA*** & MALAYSIA $* * *$ & MALAYSIA *** \\
\hline & THAILAND**** & THAILAND $* * *$ & SINGAPORE*** & THAILAND $* * * *$ \\
\hline & & & THAILAND*** & \\
\hline \multirow{10}{*}{$\begin{array}{c}\text { III } \\
\text { (Low-Low) }\end{array}$} & BULGARIA $* * *$ & BULGARIA $* * *$ & BULGARIA $* * *$ & SLOVENIA*** \\
\hline & EGYPT*** & EGYPT $* * *$ & EGYPT*** & BULGARIA $* * *$ \\
\hline & LITHUANIA*** & LITHUANIA*** & LITHUANIA $* * *$ & EGYPT*** \\
\hline & SLOVENIA $* * *$ & SLOVENIA *** & SLOVENIA $* * *$ & LITHUANIA $* * *$ \\
\hline & UKRAINE*** & UKRAINE*** & UKRAINE*** & UKRAINE*** \\
\hline & ALGERIA $* * *$ & ALGERIA $* * *$ & ALGERIA **** & ALGERIA $* * *$ \\
\hline & INDONESIA** & LUXEMBOURG ${ }^{* * *}$ & LUXEMBOURG ${ }^{* * * *}$ & LUXEMBOURG**** \\
\hline & ISRAEL & INDONESIA** & INDONESIA** & INDONESIA** \\
\hline & IRAN & ISRAEL & IRAN & IRAN \\
\hline & & IRAN & ISRAEL & ISRAEL \\
\hline \multirow{13}{*}{$\begin{array}{c}\text { IV } \\
\text { (High-Low) }\end{array}$} & AUSTRALIA $* * *$ & AUSTRALIA $* * *$ & AUSTRALIA $* * *$ & AUSTRALIA $* * *$ \\
\hline & ROMANIA $* * *$ & ROMANIA*** & ROMANIA $* * *$ & ROMANIA $* * *$ \\
\hline & LUXEMBOURG ${ }^{* * *}$ & AUSTRIA*** & ITALY $^{* * *}$ & AUSTRIA $* * *$ \\
\hline & SWITZERLAND**** & ITALY*** & SWITZERLAND $* * * *$ & SWITZERLAND**** \\
\hline & AUSTRIA $* * *$ & SWITZERLAND*** & AUSTRIA** & ITALY $* * *$ \\
\hline & ITALY $* * *$ & NETHERLANDS & BELGIUM & NETHERLANDS \\
\hline & NETHERLANDS & BELGIUM & NETHERLANDS & FRANCE \\
\hline & FRANCE & FRANCE & FRANCE & BELGIUM \\
\hline & BELGIUM & SAUDI ARABIA & UAE & SAUDI ARABIA \\
\hline & SAUDI ARABIA & POLAND & POLAND & UAE \\
\hline & UAE & UAE & SAUDI ARABIA & POLAND \\
\hline & POLAND & UK & UK & UK \\
\hline & UK & & & \\
\hline
\end{tabular}

Notes. *significant at the level $0.1 * * *$ significant at the level $0.05 * * *$ significant at the level 0.01 

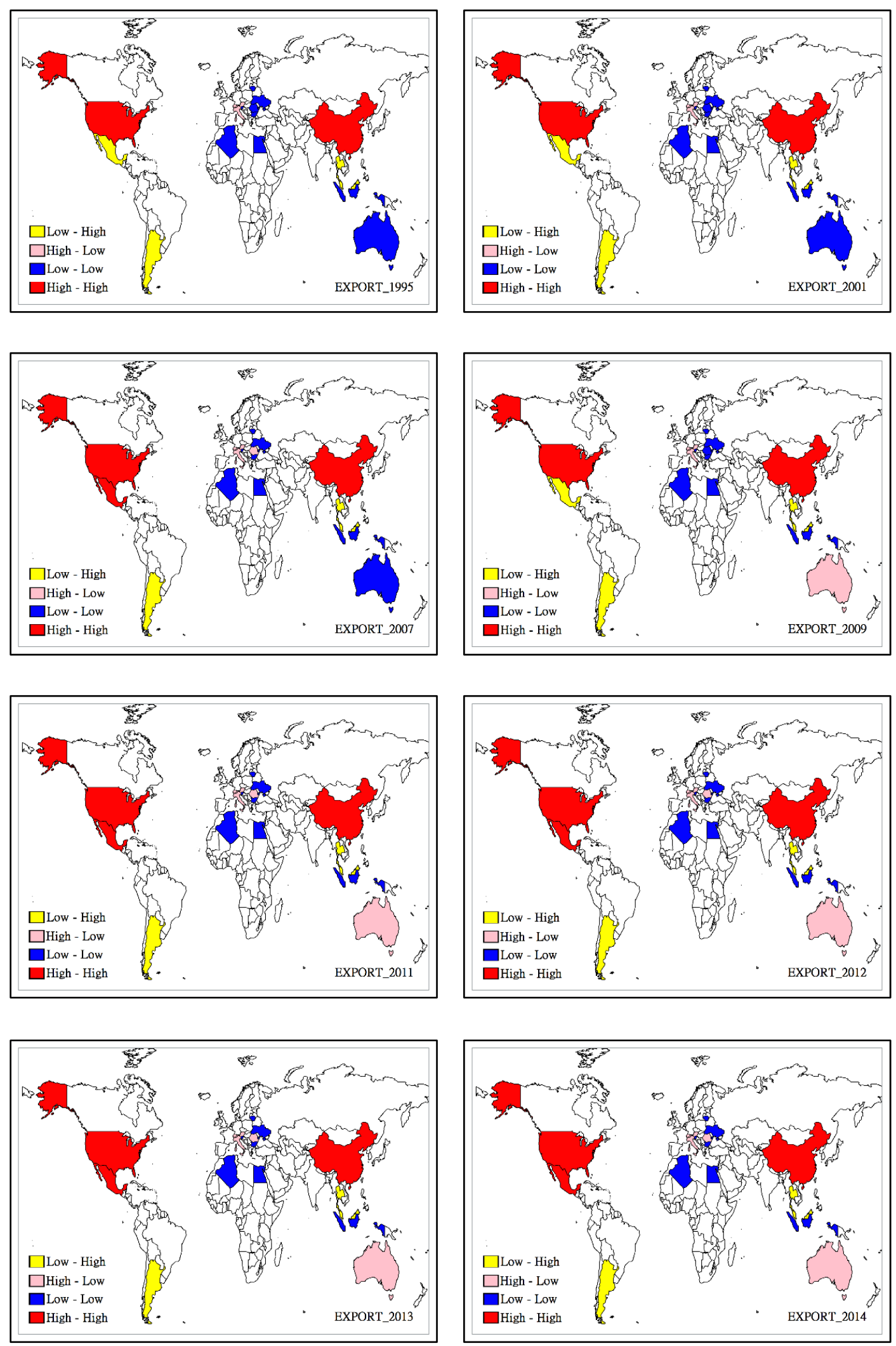

Figure 2. Changing Destinations with significant Moran's I value of German Exports 
The changing geospatial distribution of German exports contributed to its increasing export volumes. We then drew attention to what factors attracted German exports to different countries around the world. Spatial econometric models were constructed to investigate determinants of German exports.

Firstly, the econometric model of non-spatial-interaction effects can be set up as follows. We then conducted a comparison on the explanatory power of three models based on the Equation 1. Results are presented in Table 3. The R-squared of the Pooled OLS is 0.6410. The R-squared of the SLM is 0.9399. The R-squared of the SEM is 0.9391. Clearly, the explanatory power of the SLM or the SEM is higher than the conventional Pooled OLS. Furthermore, log likelihood value of the Pooled OLS is lower than that of both the SLM and the SEM. This again indicates that the fitness of the SLM and the SEM is more superior to that of non-spatial models for the panel data in this study. In addition, the log likelihood statistics of the SLM (-238.87631) is higher than that of the SEM (-243.12964). It signifies that the SLM is a better fit model than the SEM for this panel data (see also Table 3).

To identify if there are spatial effects and time-period effects in terms of the model (shown in Equation (1)), we utilized the Likelihood Ratio (LR) test. The LR test examines two null hypotheses: $H_{0}: \boldsymbol{\mu}_{i}=0$ for spatial effects and $H_{0}: v_{t}=0$ for the time-period effects. $H_{0}: \boldsymbol{\mu}_{i}=0$ is rejected because the statistics of LR test for spatial effects is 45.5837 ( $\mathrm{P}$-value $=0.034$ ) which is presented in Table 4. It signifies that this model has spatial effects. In addition, $H_{0}: v_{t}=0$ is rejected because the statistics of LR test for time-period effects is 347.8161 ( $\mathrm{P}$-value $=0.00000$ ). Thus, this model has time-period effects. Overall, the LR test results displayed in Table 4 indicate that the model has joint significant spatial and time-period fixed effects.

Table 4 also presents statistics of the Hausman test: -13.5524 (P-value=0.0597). Huasman test is employed to determine whether the fixed effects model or the random effects model is appropriate to be applied when the best fit spatial model specification is identified through the above tests. The fixed effects model is to be adopted if the Hausman test results are significant. Random effects model is to be adopted if this test result is insignificant. Thus, fixed effects model is adopted in this study because the P-value is below 0.1 and is at the significant level.

On the other hand, the LM (Lagrange Multiplier) test statistics of the SEM: 0.0397 ( $\mathrm{P}$-value=0.842) is statistically insignificant while that of the SLM: $6.3088(\mathrm{P}$-value=0.012) is statistically significant according to Table 4. Thus, the SEM is not the best fit model in comparison with the SLM. We further used the robust LM test in examining the fitness of the SLM. The statistics: 10.7019 ( $\mathrm{P}$-value=0.001 as shown in Table 4) signifies that SLM is suitable to be applied. This result is consistent with that of Table 3. We therefore modify the model displayed in Equation (1) into the SLM as follows.

$$
\begin{aligned}
\operatorname{lnEXPORT}_{i t}= & \beta_{1} \cdot \ln \mathrm{IMPORT}_{i t}+\beta_{2} \cdot \ln \mathrm{GDPPC}_{i t}+\beta_{3} \cdot \ln E R_{i t}+\beta_{4} \cdot \mathrm{KOF}_{i t} \\
& +\beta_{5} \cdot \ln \mathrm{OFDI}_{i t}+\beta_{6} \cdot E I_{i t}+\rho \sum W_{i j} \times E X P O R T_{j t}+\mu_{i}+v_{t}+\varepsilon_{i t}
\end{aligned}
$$

The Wald test is employed to investigate if the null hypothesis test: $\mathrm{H} 0: \theta=0$ is rejected and then the SDM is the correct model to be applied and is more favored on the research than the SLM. The Wald test statistics: 12.0132 (P-value $=0.0617)$ is statistically significant as shown in Table 5. Thus, it indicates that the SDM is more favored than the SLM in this study. Thus, we again modify the model as displayed in Equation (2) into Equation (3) as follows.

$$
\begin{aligned}
\operatorname{lnEXPORT}_{i t} & =\beta_{1} \cdot \ln \operatorname{IMPORT}_{i t}+\beta_{2} \cdot \ln \mathrm{GDPPC}_{i t}+\beta_{3} \cdot \ln E R_{i t}+\beta_{4} \cdot \mathrm{KOF}_{i t} \\
& +\beta_{5} \cdot \ln \mathrm{OFDI}_{i t}+\beta_{6} \cdot E I_{i t}+\rho \sum W_{i j} \times \ln E X P O R T_{j t}+\gamma_{1} \sum W_{i j} \times \ln I M P O R T_{j t} \\
& +\gamma_{2} \sum W_{i j} \times \ln G D P P C_{j t}+\gamma_{3} \sum W_{i j} \times \ln E R_{j t}+\gamma_{4} \sum W_{i j} \times K O F_{j t} \\
& +\gamma_{5} \sum W_{i j} \times \ln \operatorname{IFDI}_{j t}+\gamma_{6} \sum W_{i j} \times E I_{j t}+\mu_{i}+v_{t}+\varepsilon_{i t}
\end{aligned}
$$

In the case of SDM results, it can be decomposed from overall effects (total effects) into direct effects and indirect effects with the use of partial derivatives (LeSage and Pace 2009). The direct effect consists of the direct and feedback effects from its neighboring countries. On the other hand, the estimate of indirect effects covers the spatial spillover effects. The direct and indirect effect yield an interpretation of spatial effect, so researchers can comprehend the source of spillover effects more clearly from the decomposition. Therefore, direct, indirect, and total effects of each independent variable are exhibited from Column 2 to 4 of Table 5. It shows that IMPORT, GDPPC, and EI are significant explanatory factors to German exports while ER, KOF, and OFDI are totally insignificant. 
Table 4. Results estimated by the Pooled OLS and with Spatial Interaction Effects on EXPORT

\begin{tabular}{|c|c|c|c|}
\hline Determinants & Pooled OLS & SLM & SEM \\
\hline $\operatorname{lnIMPORT_{i,t}}$ & $\begin{array}{c}0.550300 * * * \\
(0.000000)\end{array}$ & $\begin{array}{c}0.551768 * * * \\
(0.000000)\end{array}$ & $\begin{array}{c}0.549780 * * * \\
(0.000000)\end{array}$ \\
\hline $\ln G D P P C_{i, t}$ & $\begin{array}{c}0.190495 * * * \\
(0.000000)\end{array}$ & $\begin{array}{c}0.190153 * * * * \\
(0.000001)\end{array}$ & $\begin{array}{c}0.190281 * * * \\
(0.000001)\end{array}$ \\
\hline $\ln E R_{i, t}$ & $\begin{array}{c}0.005280 \\
(0.828889)\end{array}$ & $\begin{array}{c}0.007567 \\
(0.763593)\end{array}$ & $\begin{array}{c}0.005249 \\
(0.835720)\end{array}$ \\
\hline$K O F_{i, t}$ & $\begin{array}{l}-0.003985 \\
(0.178020)\end{array}$ & $\begin{array}{l}-0.004190 \\
(0.168421)\end{array}$ & $\begin{array}{l}-0.004016 \\
(0.189946)\end{array}$ \\
\hline $\ln O F D I_{i, t}$ & $\begin{array}{c}0.043299 \\
(0.559502)\end{array}$ & $\begin{array}{c}0.032151 \\
(0.673875)\end{array}$ & $\begin{array}{c}0.042690 \\
(0.580217)\end{array}$ \\
\hline$E I_{i, t}$ & $\begin{array}{l}0.070792 * * \\
(0.014005)\end{array}$ & $\begin{array}{l}0.073789 * * \\
(0.012642)\end{array}$ & $\begin{array}{l}0.070902 * * \\
(0.017382)\end{array}$ \\
\hline $\mathrm{W}^{*}$ dep.var & - & $\begin{array}{l}-0.148974 * \\
(0.056179)\end{array}$ & - \\
\hline spat.aut. & - & - & $\begin{array}{l}0.195517 * * \\
(0.028100)\end{array}$ \\
\hline Log likelihood & -243.1489 & -238.87631 & -243.12964 \\
\hline$\sigma^{2}$ & 0.1330 & 0.1410 & 0.1433 \\
\hline$R^{2}$ & 0.6410 & 0.9399 & 0.9391 \\
\hline
\end{tabular}

Notes. 1. Figures in parentheses are the $\mathrm{P}$-value.

2.*Significance at level 0.1,**Significance at level $0.05, * * *$ Significance at level 0.01.

Table 5. Results estimated without Spatial Interaction Effects on EXPORT

\begin{tabular}{|c|c|c|c|c|}
\hline Determinants & $\begin{array}{l}\text { No spatial \& time-specific } \\
\text { fixed effects }\end{array}$ & $\begin{array}{c}\text { Spatial } \\
\text { fixed effects }\end{array}$ & $\begin{array}{l}\text { Time-period } \\
\text { fixed effects }\end{array}$ & $\begin{array}{c}\text { Spatial and } \\
\text { Time-period fixed } \\
\text { effects }\end{array}$ \\
\hline $\operatorname{lnIMPORT} T_{i, t}$ & $\begin{array}{c}0.738586 * * * \\
(0.000000)\end{array}$ & $\begin{array}{c}0.739328 * * * \\
(0.000000)\end{array}$ & $\begin{array}{c}0.557684 * * * \\
(0.000000)\end{array}$ & $\begin{array}{c}0.550300 * * * \\
(0.000000)\end{array}$ \\
\hline $\ln G D P P C_{i, t}$ & $\begin{array}{c}0.311888 * * * \\
(0.000000)\end{array}$ & $\begin{array}{c}0.308141 * * * \\
(0.000000)\end{array}$ & $\begin{array}{c}0.190827 * * * \\
(0.000000)\end{array}$ & $\begin{array}{c}0.190495 * * * \\
(0.000000)\end{array}$ \\
\hline $\ln E R_{i, t}$ & $\begin{array}{c}0.019821 \\
(0.381497)\end{array}$ & $\begin{array}{c}0.030064 \\
(0.179961)\end{array}$ & $\begin{array}{l}-0.012620 \\
(0.613201)\end{array}$ & $\begin{array}{c}0.005280 \\
(0.828889)\end{array}$ \\
\hline$K O F_{i, t}$ & $\begin{array}{l}-0.005586^{*} \\
(0.058290)\end{array}$ & $\begin{array}{l}-0.005176^{*} \\
(0.076127)\end{array}$ & $\begin{array}{l}-0.004052 \\
(0.177248)\end{array}$ & $\begin{array}{l}-0.003985 \\
(0.178020)\end{array}$ \\
\hline $\ln O F D I_{i, t}$ & $\begin{array}{c}0.099812 \\
(0.293152)\end{array}$ & $\begin{array}{c}0.101233 \\
(0.285720)\end{array}$ & $\begin{array}{c}0.028943 \\
(0.699893)\end{array}$ & $\begin{array}{c}0.043299 \\
(0.559502)\end{array}$ \\
\hline$E I_{i, t}$ & $\begin{array}{c}-0.058790^{* * *} \\
(0.034253)\end{array}$ & $\begin{array}{l}-0.051649^{*} \\
(0.059632)\end{array}$ & $\begin{array}{l}0.055452 * \\
(0.058392)\end{array}$ & $\begin{array}{c}-0.070792 * * \\
(0.014005)\end{array}$ \\
\hline $\begin{array}{l}\text { Log likelihood } \\
\sigma^{2} \\
R^{2}\end{array}$ & $\begin{array}{c}-430.7187 \\
0.2490 \\
0.8861 \\
\end{array}$ & $\begin{array}{c}-417.0570 \\
0.2375 \\
0.8900 \\
\end{array}$ & $\begin{array}{l}-265.9408 \\
0.1435 \\
0.6354 \\
\end{array}$ & $\begin{array}{c}-243.1489 \\
0.1330 \\
0.6410 \\
\end{array}$ \\
\hline LM test no spatial lag & $\begin{array}{l}171.9034 * * * \\
(0.000)\end{array}$ & $\begin{array}{l}181.3464 * * * \\
(0.000)\end{array}$ & $\begin{array}{l}5.9909 * * \\
(0.014)\end{array}$ & $\begin{array}{c}6.3088^{* *} \\
(0.012)\end{array}$ \\
\hline LM test no spatial error & $\begin{array}{l}479.6996 * * * \\
(0.000)\end{array}$ & $\begin{array}{l}528.9410 * * * \\
(0.000)\end{array}$ & $\begin{array}{l}0.3280 \\
(0.567)\end{array}$ & $\begin{array}{l}0.0397 \\
(0.842)\end{array}$ \\
\hline robust LM test no spatial lag & $\begin{array}{l}34.5668 * * * \\
(0.000)\end{array}$ & $\begin{array}{l}34.9442 * * * \\
(0.000)\end{array}$ & $\begin{array}{l}8.0378 * * * \\
(0.005)\end{array}$ & $\begin{array}{l}10.7019 * * * \\
(0.001)\end{array}$ \\
\hline robust LM test no spatial error & $\begin{array}{c}342.3630 * * * \\
(0.000) \\
\end{array}$ & $\begin{array}{c}382.5388 * * * \\
(0.000) \\
\end{array}$ & $\begin{array}{l}2.3749 \\
(0.123) \\
\end{array}$ & $\begin{array}{c}4.4328 * * \\
(0.035) \\
\end{array}$ \\
\hline $\begin{array}{l}\text { LR-test joint significance } \\
\text { spatial fixed effects } \\
\text { LR-test joint significance } \\
\text { time-periode fixed effects }\end{array}$ & & $\begin{array}{r}45.583 \\
(0.03 \\
347.816 \\
(0.00\end{array}$ & & \\
\hline Hausman test & & $\begin{array}{r}-13.55 \\
(0.05)\end{array}$ & & \\
\hline
\end{tabular}

Notes.1. Figures in parentheses are the P-value.

2.*Significance at level $0.1, * *$ Significance at level $0.05, * * *$ Significance at level 0.01 .

The independent variable, IMPORT coefficient had very significant and positive direct and total effects, though it also had significant negative indirect effects. This signifies that a nation with a strong imports connection with 
Germany is also a major German export destination. On the other hand, neighboring countries of German import trade partner nations did not necessarily share the same strong imports relationship with Germany. In other words, German exports did not have a significant spillover effect from the neighboring countries of the main German import trade partner nations. With regards to total effects, IMPORT showed significantly positive effects with German exports (see Table 5) Thus, the determinant, IMPORT overall had significantly positive effects on German exports. The impacts of IMPORT can be highlighted in the case of mainland China (in light of results from Moran's I aforementioned). Mainland China is one of the German main export destination countries and is the second largest importing country to Germany during this period according to the data from the Datastream. Indeed, the study of Simonazzi et al. (2013) found that imports of low-end and mid-range price segment apparel/clothing goods from mainland China to Germany has an enlarging share of $45.8 \%$ in 1999 to 84.09 in 2008. The other major export-destination countries of Germany, such as USA, Switzerland, Austria, and Italy, are all in the top ten largest import countries of Germany according to data from the Datastream.

GDPPC represents GDP per capita in trade partner countries and it had significant positive direct but insignificant indirect, and total effects on German exports. According to the result of Moran's I, the main German export-destination countries include: Switzerland, Austria, Italy, USA, Australia, and Singapore. The above countries are all countries with high GDP per capita. These countries mostly were categorized at the High-Low quadrant. They also match well on impacts GDPPC on German exports. Thus, GDPPC only has strong direct effects and has no indirect effects. They could afford to purchase high-end luxury vehicles and demanded capital-intensive and technology-intensive machinery from the Germany.

Meanwhile, regarding economic integration $(E I)$, it has significant direct effects, though there are no significant indirect and total effects. Thus, the degree of bilateral economic integration between Germany and its trade partners was identified to have significantly positive direct effects and have insignificant indirect and total effects. German main export-destination countries, such as Austria and Italy, are both member countries of the EU, and to a broader extent, Switzerland can be applied to benefit from the economic integration of the EU. Also, the USA, which was categorized at the High-High quadrant throughout the period of this study, and Mexico, which was categorized at the High-High quadrant in 2007 and from 2011 to 2014, can be attributed to the NAFTA and the free trade agreements with other emerging economies in Central and South America countries in recent years. The case of Singapore, a city state, which was categorized at the High-High quadrant from 2011 to 2014, should also be attributed to the economic integration with other South East Asian countries, such as: ASEAN (Association of SouthEast Asian Nations).

To sum up, we identified that German exports are highly correlated to its imports. This signifies that German exports built upon those already close economic relation in some countries. Trade flows are not only one-way exports, imports are highly related to Germany exports. These apply to countries such as mainland China, Switzerland, Austria, and Italy. In addition, German goods are mainly exported to countries with high GDP per capita. Thus, these countries are capable of purchasing high-end luxury automobiles and demanded price-inelastic and high-quality German goods. German exports benefited from the free trade flow to a few EU member countries. These countries are geographically and culturally close to Germany.

\section{Concluding Remarks}

Despite the outstanding performances of German exports, there is a lack of research on German export performances with spatial econometric evidences. This paper aims to fill the gap in the existing literature to investigate the changing geospatial distribution of its exports and identify the decisive factors to its outstanding performances over decades.

Results of the Moran's I clearly show us that German exports have kept the USA, China, Switzerland, Italy, and Australia as its major export destinations over the past two decades. It further expanded and strengthened its market shares in other North American countries. It also broadened its export destinations to many Asia Pacific countries. In short, it has expanded and diversified its export destination countries with increasing export-volume growth over the past two decades.

The changing geospatial distribution of German exports contributed to its increasing export volumes. Interestingly, empirical evidences of the SDM are quite consistent with those of Moran's I. They indicate that German exports were highly correlated to its imports. It signifies that German exports built upon certain close economic relationships. Trade flows are one-way exports, while imports are highly related to Germany exports. This connection applies to countries such as mainland China, Switzerland, Austria, and Italy. In addition, German goods were mainly exported to countries with high GDP per capita. Thus, these countries were capable of purchasing high-end luxury automobiles and demanded price-inelastic and high-quality German goods. 
German exports benefited from the free trade flow to a few EU member countries, those are close geographically and culturally to Germany. Its exports successfully broadened from Europe to other countries in America and the Asia Pacific region with increasing total export-volume growth.

Table 6. Results estimated of SDM model on EXPORT

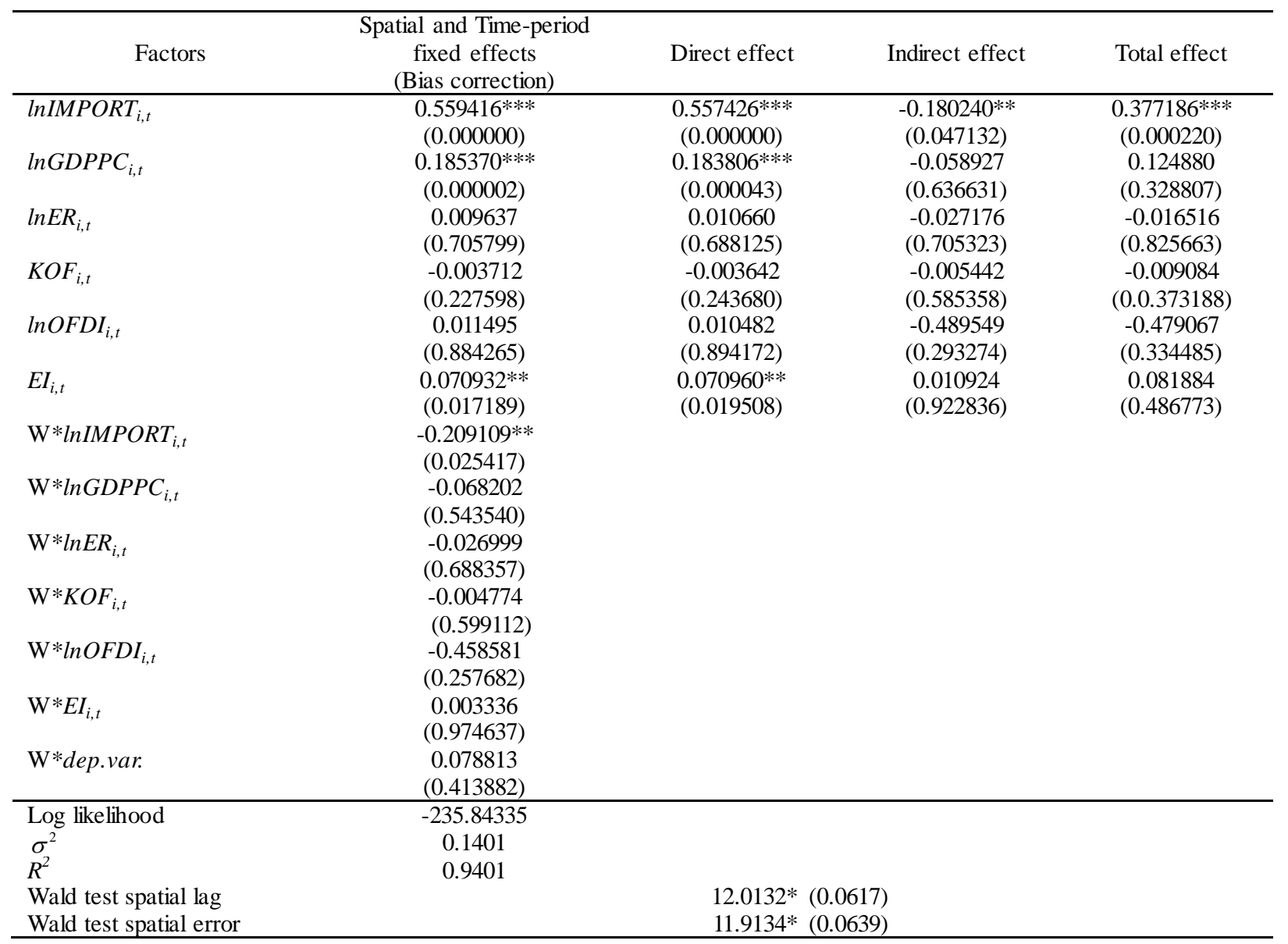

Notes. 1. Figures in parentheses are the $\mathrm{P}$-value.

\section{References}

2.*Significance at level $0.1, * *$ Significance at level $0.05, * * *$ Significance at level 0.01 .

Agostino, M., Demaria, F., \& Trivieri, F. (2010). Non-Reciprocal Trade Preferences and the Role of Compliance Costs in the Agricultural Sector: Exports to the EU. Journal of Agricultural Economics, 61(3), 652-679. https://doi.org/10.1111/j.1477-9552.2010.00264.x

Anderson, J., \& Marcouiller, D. (2002). Insecurity and the Pattern of Trade: An Empirical Investigation. Review of Economics and Statistics, 84(2), 342-352. https://doi.org/10.1162/003465302317411587

Anderton, B. (1999). Innovation, product quality, variety, and trade performance: an empirical analysis of Germany and the UK. Oxford Economic Papers, 51(1), 152-167. https://doi.org/10.1093/oep/51.1.152

Anselin, L. (1995). Local indicators of spatial association - LISA. Geographical Analysis, 27(2), 93-115. https://doi.org/10.1111/j.1538-4632.1995.tb00338.x

Anselin, L. (1988). Spatial econometrics: methods and models (1st ed.). Dordrecht: Kluwer Academic Publishers. https://doi.org/10.1007/978-94-015-7799-1

Aten, B. (1997). Does Space Matter? International Comparison of the Prices of Tradables and Nontradables. International Regional Science Review, 20(1-2), 35-52. https://doi.org/10.1177/016001769702000103

Balassa, B. (1961). Towards A Theory of Economic Integration. KYKLOS, 14(1), 1-17. https://doi.org/10.1111/j.1467-6435.1961.tb02365.x

Balassa, B. (1978). Exports and Economic Growth: Further Evidence. Journal of Development Economics, 5(2), 181-189. https://doi.org/10.1016/0304-3878(78)90006-8 
Bartram, S. (2004). Linear and Nonlinear Foreign Exchange Rae Exposures of German Nonfinancial Corporations. Journal of International Money and Finance, 23(4), 673-699. https://doi.org/10.1016/j.jimonfin.2004.03.002

Belke, A., Gocke, M., \& Gunther, M. (2013). Exchange Rate Bands of Inaction and Play-Hysteresis in German Exports-Sectoral Evidence for some OECD Destinations. Metroeconomica, 64(1), 152-179. https://doi.org/10.1111/meca.12000

Bjorvatn, K. (2004). Economic Integration and the Profitability of Cross-Border Mergers and Acquisitions. European Economic Review, 48(6), 1211-1226. https://doi.org/10.1016/j.euroecorev.2004.03.007

Blonigen, B., Davies R., Waddell G., \& Naughton H. (2007). FDI in Space: Spatial Autoregressive Relationships in Foreign Direct Investment. European Economic Review, 51(5), 1303-1325. https://doi.org/10.1016/j.euroecorev.2006.08.006

Danninger, S., \& Joutz, F. (2007). What Explains Germany's Rebounding Export Market Share? CESifo Economic Studies, 54(4), 681-714. https://doi.org/10.1093/cesifo/ifn030

Eichengreen, B., Rhee, Y., \& Tong, H. (2004). The Impacts of China on the Exports of Other Asian Countries. NBER Working Paper No. 10768, National Bureau of Economic Research, Cambridge, MA. https://doi.org/10.3386/w10768

Egger, P. (2001). European Exports and Outward Foreign Direct Investment: A Dynamic Panel Data Approach. Review of World Economics, 137(3), 427-449. https://doi.org/10.1007/BF02707625

Egger, P., \& Pfaffermayr, M. (2004). Distance, trade and FDI: a Hausman-Taylor SUR Approach. Journal of Applied Econometrics, 19(2), 227-246. https://doi.org/10.1002/jae.721

Ekoholm, K., Forslid, R., \& Markusen, J. (2007). Export-Platform Foreign Direct Investment. Journal of European Economic Association, 5(4), 776-795. https://doi.org/10.1162/JEEA.2007.5.4.776

Esfahani, H. (1991). Exports, Imports, and Economic Growth in Semi-industrialized Countries. Journal of Development Economics, 35(1), 93-116. https://doi.org/10.1016/0304-3878(91)90068-7

Fung, H., Sawhney, B., Lo, W., \& Xiang, P. (1994). Exports, Imports and Industrial Production: Evidence from Advanced and Newly Industrializing Countries. International Economic Journal, 8(4), 87-98. https://doi.org/10.1080/10168739400080031

Getis, A., \& Ord, J.K. (1992). The Analysis of Spatial Association by Use of Distance Statistics. Geographical Analysis, 24(3), 189-206. https://doi.org/10.1111/j.1538-4632.1992.tb00261.x

Geary, R. C. (1954). The Contiguity Ratio and Statistical Mapping. The Incorporated Statistician, 5(3), 115-145. https://doi.org/10.2307/2986645

Greenway, D., \& Kneller, R. (2007) Firm Heterogeneity, Exporting and Foreign Direct Investment. The Economic Journal, 117(517), F134-F161. https://doi.org/10.1111/j.1468-0297.2007.02018.x

Halleck Vega, S., \& Elhorst, J. (2012). On Spatial Econometric Models, Spillover Effects, and W. Working paper, University of Groningen, The Netherlands.

Hooper, P., \& Kohlhagen, S. (1978). The Effect of Exchange Rate Uncertainty on the Prices and Volume of International Trade. Journal of International Economics, 8(4), 483-511. https://doi.org/10.1016/0022-1996(87)90001-8

Hwang, H., Mai, C.C., \& Ohta, H. (2010). Export Subsidies, Cost Differential and Product Quality. Pacific Economic Review, 15(1), 32-41.https://doi.org/10.1111/j.1468-0106.2009.00487.x

Jannsen, N., \& Kooths, S. (2012). German Trade Performance in Times of Slumping Euro Area Markets. Intereconomics, 47(6), 368-372. https://doi.org/10.1007/s10272-012-0439-2

Katsikeas, C., Piercy, N., \& Ioannidis, C. (1996). Determinants of Export Performance in a European Context. European Journal of Marketing, 30(6), 6-35. https://doi.org/10.1108/03090569610121656

LeSage, J., \& Pace, R., (2009). Introduction to spatial econometrics. Boca Raton, US: CRC Press Taylor \& Francis Group. https://doi.org/10.1201/9781420064254

Moran, P. A. P. (1950). Notes on Continuous Stochastic Phenomena. Biometrika, 37(1), 17-23. https://doi.org/10.1093/biomet/37.1-2.17

Morrow, J, Siverson, R., \& Tabares, T. (1998). The Political Determinants of International Trade: The Major 
Powers, 1907-1990. American Political Science Review, 92(3), 649-661. https://doi.org/10.2307/2585487

Pain, N., \& Wakelin, K. (1998), Export Performance and the Role of Foreign Direct Investment. The Manchester School, 66(S), 62-88. https://doi.org/10.1111/1467-9957.66.s.4

Roper, S., \& Love, J. (2002). Innovation and Export Performance: Evidence from the UK and German Manufacturing Plants. Research Policy, 31(7), 1087-1102. https://doi.org/10.1016/S0048-7333(01)00175-5

Rothwell, R. (1981). Non-Price Factor in the Export Competitiveness of Agricultural Engineering Products. Research Policy, 10(3), 260-288. https://doi.org/10.1016/0048-7333(91)90041-N

Schott, P. (2010). U.S. Manufacturing Exports and Imports by SIC or NAICS Category and Partner Country, 1972 to 2005. Working paper, Yale School of Management, New Haven, CT.

Simonazzi, A., Ginzburg, A., \& Nocella, G. (2013). Economic Relations Between Germany and Southern Europe. Cambridge Journal of Economics, 37(3), 653-675. https://doi.org/10.1093/cje/bet010

Sinn, H. (2006). The Pathological Export Boom and the Bazaar Effect: How to Solve the German Puzzle. World Economy, 29(9), 1157-1175. https://doi.org/10.1111/j.1467-9701.2006.00841.x

Stahn, K. (2007). Has the Export Pricing Behavior of German Enterprises Changed? Empirical Evidence from German Sectoral Export Prices. Journal of Economics and Statistics, 227(3), 295-329.

Winters, L. (1985). Separability and the Modelling of International Economic Integration: U.K. Exports to Five Industrial Countries. European Economic Review, 27(3), 335-353. https://doi.org/10.1016/S0014-2921(85)80019-2

Yasar, M., \& Paul, C. (2007). International Linkage and Productivity at the Plant Level: Foreign Direct Investment, Exports, Imports, and Licensing. Journal of International Economics, 71(2), 373-388. https://doi.org/10.1016/j.jinteco.2006.03.004

Yeaple, S. (2003). The Role of Skill Endowments in the Structure of U.S. Outward Foreign Direct Investment. The Review of Economics and Statistics, 85(3), 726-734. https://doi.org/10.1162/003465303322369849

\section{Copyrights}

Copyright for this article is retained by the author(s), with first publication rights granted to the journal.

This is an open-access article distributed under the terms and conditions of the Creative Commons Attribution license (http://creativecommons.org/licenses/by/4.0/). 